症例

\title{
ダナパロイドナトリウムが奏効した脾摘後門脈血栓症の 1 例
}

北海道厚生連札幌厚生病院外科

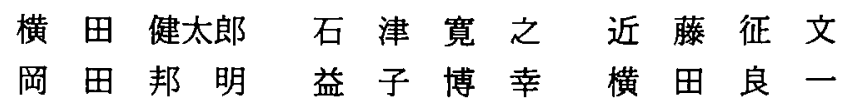

症例は48歳女性. C 型肝硬変, 肝細胞癌 $(\mathrm{HCC})$, 脾腫による汎血球減少の診断て腫瘍 切除および血小板增加を目的とした脾摘を企図した。肝 S3の部分切除および脾摘を施行 したが，術後 6 日目のCT 検査で門脈内に血栓を認めた．同日よりダナパロイドナトリ ウムを投与したところ投与開始後12日目で血栓は消失した．ダナパロイドナトリウムは ヘパリンナトリウムに比べ,出血傾向などの副作用を生じにくい新しい抗凝固郕である. 本邦で蜼種性血管内凝固症候群のみが適応となっているが, 欧米では肺血栓塞栓症な ど哚部静脈血栓症に対しても広く適応とされ本症例においてもその有効性が示された。

索引用語：ダナパロイドナトリウム, 門脈血栓症, 脾摘

\section{緒言}

脾摘術後の門脈血栓形成は $4.4 \sim 25 \%$ と比較的多く の症例でみられ $れ^{(12)}$, 門脈圧え進症を有する症例ではさ らに高頻度である ${ }^{3 / 4)}$. 進行すれば腸壊死や肝不全など の発生があり得るため,その予防や治療が重要である.

今回われわれは門脈圧六進症例の脾摘後に生じた門 脈血栓に対しダナパロイドナトリウム投与を行い血栓 消失をえた症例を経験した。

\section{症 例}

患者: 48歳, 女性.

既往歴：14歳, 虫垂切除術. 34藏, 出産時の子宮口 裂傷で輸血歴がある。

家族歴：特記事項なし。

現病歴：1994年にC 型肝硬変を指摘され前医に通 院していた.2003年12月, US 抒よびMRIで肝 S3に肝 細胞癌 (HCC) を発見されたため, 当院消化器科を紹 介され翌年 1 月13日入院した。肝腫崵切除とともにイ ンターフェロン治療導入前の血小板增加を目的とした 脾摘を行うため, 同月29日当科へ転科となった。

入院時検査所見: $\mathrm{HCV}$ 陽性で, 白血球 $2,100 / \mu \mathrm{l}$ $(3,000 \sim 7,800)$, ヘモグロビン $9.1 \mathrm{~g} / \mathrm{dl}$ $(10.6 \sim 14.4)$, 血小板 $3.7 \times 10^{4} / \mu \mathrm{l} \quad(13.8 \sim 30.9 \times$

2004 年12月 3 日受付 2005 年 1 月 25 日採用 〈所属施設住所〉

于060-0033 札幌市中央区北三条東 8 丁目 5
104) と汎血球減少を認めた。腫瘍マーカーは CEA 5.8 $\mathrm{ng} / \mathrm{ml}(<5.0)$, AFP $43.5 \mathrm{ng} / \mathrm{ml}(<20.0)$ (L3分画 $<$ $0.5 \%)$, CA19-9 $39.2 \mathrm{U} / \mathrm{ml}(<37.0)$, PIVKA-II 63 $\mathrm{mAU} / \mathrm{mL}(<40.0)$ といずれも高值であった。肝機能 はアシアロシンチで $\mathrm{LHL}_{15} 0.79, \mathrm{HH}_{15} 0.82$ と moderate to severe liver dysfunction と評価された。 また Child-Pugh 分類はA（5点）であった（表 1).

上部消化管内視鏡検査: 食道静脈瘤を認め, $\mathrm{Lm}$, $\mathrm{F} 2, \mathrm{Cb}, \mathrm{RC}(-), \operatorname{Lg}(-)$ であった。

腹部造影 CT 検查：肝外側区に S3のグリソンに接 して, 動脈相で High density, 静脈相で Low density を呈する $\phi 12 \mathrm{~mm}$ 大の腫㾇を認め, HCC と診断した. 脾静脈は拡張し, 胆襄内に $\phi 7 \mathrm{~mm}$ 大の胆石を認めた (図 1 ).

\section{表 1 術前検查所見}

\begin{tabular}{|c|c|c|c|c|c|c|}
\hline WBC & 2.100 & $/ \mu]$ & $(3000 \sim 7800)$ & $\mathrm{Fe}$ & 28 & $\mu \mathrm{g} / \mathrm{dl}(43 \sim 181)$ \\
\hline $\mathrm{Hb}$ & 9.1 & $\mathrm{~g} / \mathrm{dl}$ & $(10.6 \sim 14.4)$ & APTT & 43 & $\sec \quad(26 \sim 39)$ \\
\hline Plt & $3.7 \times 10^{4}$ & \multicolumn{2}{|c|}{$/ \mu l\left(13.8 \sim 30.9 \times 10^{\circ}\right)$} & PT & 81 & $\%(90 \sim 140)$ \\
\hline Alb & 3.7 & $\mathrm{~g} / \mathrm{dl}$ & $(4.0 \sim 5.2)$ & ICG15 & 9.0 & \multirow[t]{2}{*}{$\%(0.0 \sim 10.0)$} \\
\hline GOT & 62 & IU $/$ & $(8 \sim 38)$ & & & \\
\hline GPT & 48 & IU $/]$ & $(4 \sim 44)$ & $\mathrm{HBsAg}$ & \multicolumn{2}{|r|}{$(-)$} \\
\hline ChE & $x^{2}$ & {$[U /]$} & $(97-244)$ & $\mathrm{HCV}$ & \multicolumn{2}{|r|}{$(+)$} \\
\hline LDH & 372 & $\mathrm{IU} / \mathrm{I}$ & $(180 \sim 460)$ & & & \\
\hline ALP & 270 & IU/1 & $(104-33 x)$ & CEA & 5.8 & $\mathrm{ng} / \mathrm{ml}$ \\
\hline$\gamma \mathrm{GTP}$ & & IU/] & $(5 \sim 37)$ & AFP & 43.5 & $\mathrm{ng} / \mathrm{ml} \quad(<20.0)$ \\
\hline \multirow[t]{2}{*}{ T-Bil } & $1.3 r$ & $\mathrm{ng} / \mathrm{dl}$ & $(0.2 \sim 1.2)$ & CA19-9 & 39.2 & $\mathrm{U} / \mathrm{ml} \quad(<37.0)$ \\
\hline & & & & PIVKA-II & \multicolumn{2}{|c|}{$63 \mathrm{mAU} / \mathrm{mL} \quad(<40.0)$} \\
\hline
\end{tabular}



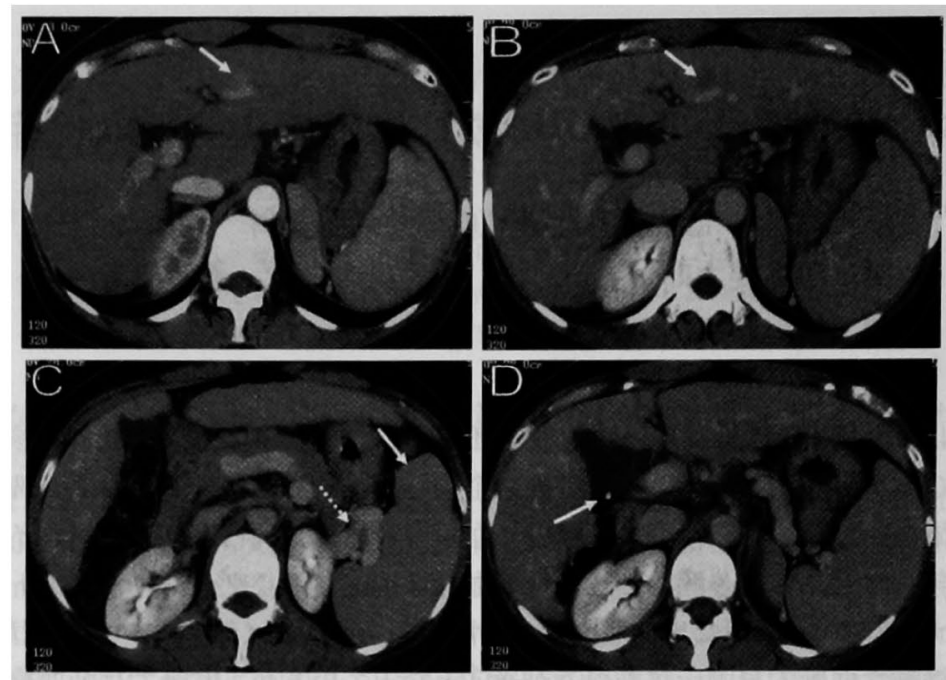

図 1 術前 CT 所見：A） S3の $\phi 12 \mathrm{~mm} の$ HCC は Early phase て High に造影される (矢印). B) Late phase で同腫癌は Low density を示す (矢印)。C）脾腫（実線矢印）とともに脾静脈の拡張（破線矢印）を認 める. D）胆董内に小結石を一個認める（矢印）。
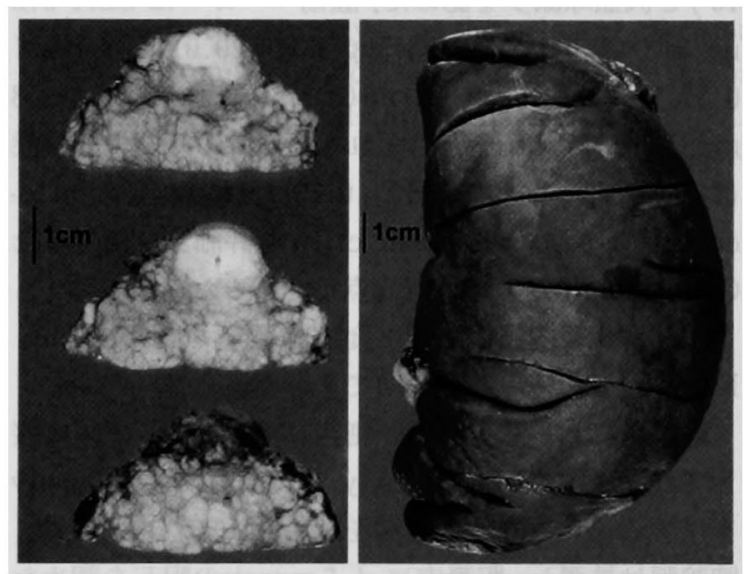

図2 摘出標本：左) 肝 S3部分切除標本. HCC は $\phi 12$ $\mathrm{mm}$ 大で単純結節周囲增殖型, 併存病変は肝硬変であっ た. 右) 脾䑏（重量 $750 \mathrm{~g}$ ).

手術所見：右下半側臥位で上腹部正中切開に左横切 開を加えて開腹した。脾動静脈を脾門部で処理し脾臓 を摘出したのち, 胆集摘出ならびに肝 S3のグリソンに 接していた肝腫瘍を切除した。この際 Pringle 法など の肝阻血操作は行わなかった。手術時間は 5 時間20分, 術中出血量は $397 \mathrm{ml}$ であった。

摘出標本：肝腫湟は最大径が $12 \mathrm{~mm}$ で肝切除重量は $23 \mathrm{~g}$ (図 2 左), 脾蔵は大きさ $18.2 \times 10.8 \times 4.5 \mathrm{~cm}$ で重

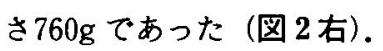

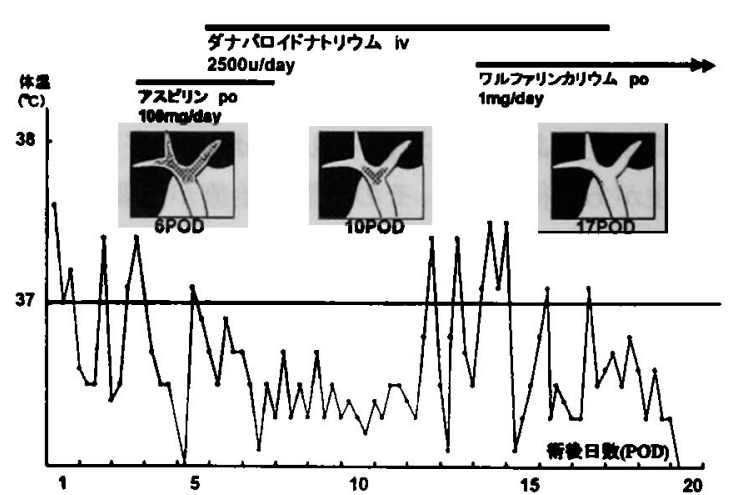

図 3 術後経過

病理所見：肝臓の組織学的所見は, 単純結節周囲増 殖型, eg, fc(-), fc-inf $(-), \operatorname{sf}(-), \mathrm{s} 0, \mathrm{vp} 0, \mathrm{vv0}$, va0, b0, im0, p0, $\mathrm{sm}(+)$ LC, 高分化型肝細胞癌, 索状型であった．脾蔵に特記すべき所見はなかった。

術後経過(図 3)：術後 4 日目まて $37.5^{\circ} \mathrm{C}$ 熱発が続

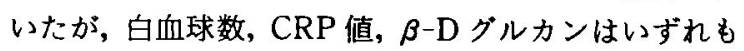
基準值範囲内にとどまり，感染は除外された。そこで 門脈血栓症を疑いアスピリン $(100 \mathrm{mg} / \mathrm{day})$ の経口投 与を開始した。術後 6 日目に施行した腹部造影 CTで 脾静脈内から門脈左右枝にまで及ふ広範な血栓形成を 認めたため, ダナパロイドナトリウム $(2,500 \mathrm{u} /$ day $)$ の静注を開始した.10日目に施行した腹部造影 CTで， 門脈左右枝まで及んていた血栓は肝門部のみに縮小し 

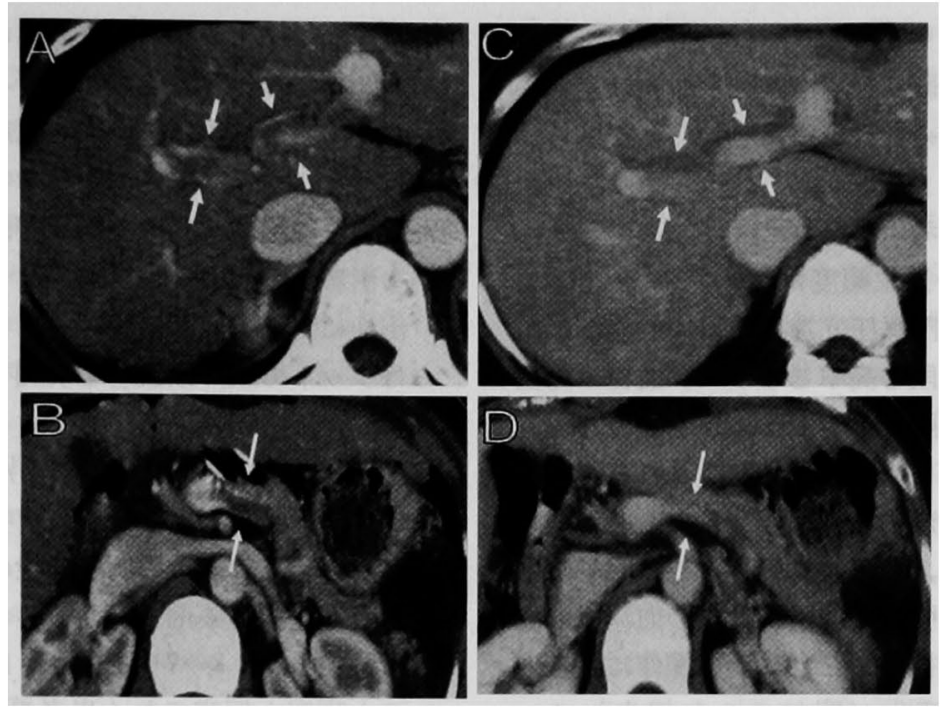

図 4 術後 CT 所見：A) 術後 6 日目の CT では血栓は門脈左右枝 (矢印) まで及んでおり，B）脾静脈内にも内腔をほほ完全に閉塞する血栓を認 める (矢印)，C）術後17日目 (タナパロイドナトリウム投与後12日目) のCTでは肝内門脈の血栓は消失し (矢印)，D)脾静脈内にわずかに認 められている(矢印).

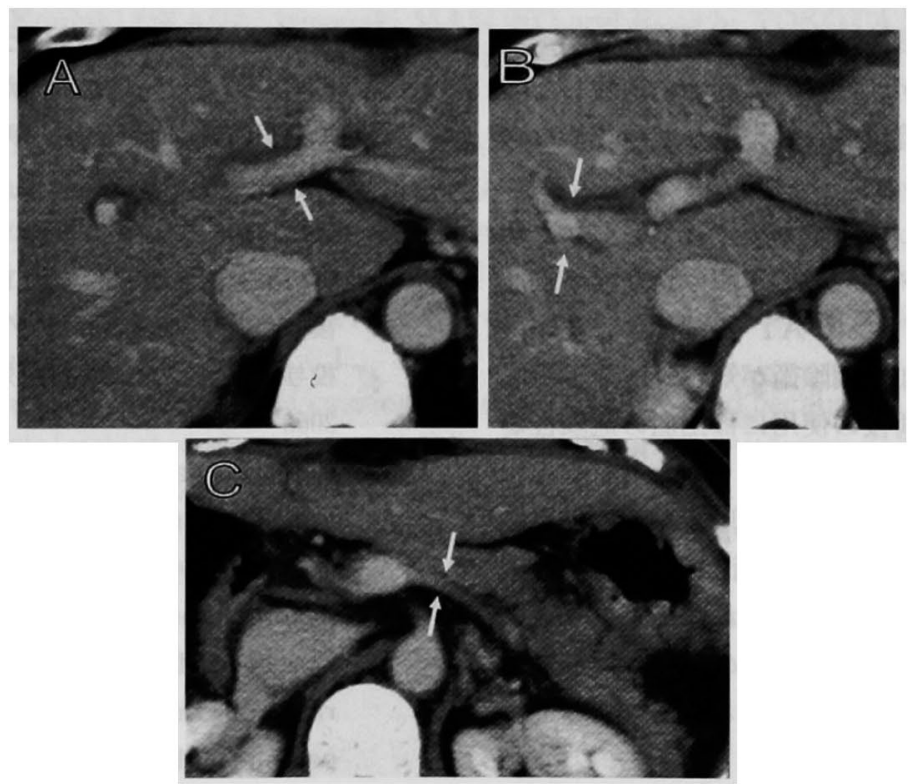

図 5 退院後 1 カ月の CT 所見：A）門脈右枝，B）門脈左枝，C）脾 静脈内に血栓は認めない。

ていた。また, 経過中に腹腔内出血, 創出血などの出 血傾向はみられなかった。術後12日目より再度熱発を 認め, 血栓の残存を疑い14日目よりワーファリンカリ ウム ( $1 \mathrm{mg} /$ day) を併用した. 術後17日目に行った腹 部造影 CTで, 門脈系血栓はほほ消失したため, 術後
18日目よりダナパロイドナトリウムを中止した（図 $4)$.

術後の血小板数の推移は, 6 日目で $10.4 \times 10^{4} / \mu 1,10$ 日目で $12.4 \times 10^{4} / \mu 1 ， 17$ 日目で $13.5 \times 10^{4} / \mu 1$ と術前と 比較し改善しており 20 日目に退院となった。退院後は 
同量のワーファリンカリウムのみを継続したが，1 月後に施行した腹部造影 CT では門脈系血栓は完全に 消失していることが認められたためその時点で投与を 中止した（図５）。

\section{考 察}

脾摘後門脈系血栓の発生頻度は $4.4 \sim 25 \%$ と比較的 高頻度である ${ }^{1 / 2)}$. 特に門脈圧方進症を呈する症例にお いては25〜 68.4\%と一段と高率となり ${ }^{3 / 4)}$, 血栓の発生 部位別では，遗残脾静脈にとどまるものが70〜85\%， 門脈本幹へまで広がるものが15〜20\%とされる ${ }^{5) 6) . ~}$

脾摘後門脈系血栓の形成の要因としては, 血管壁の 変化, 血液性状の変化, 血流速度の変化の 3 因子があ げられる，松田らは拡張した遗残脾静脈の血流うっ滞 を第 1 の因子として重視し，これに手術操作による内 膜損傷と血液性状の変化が関与すると報告してい る1)。そこて脾静脈の遺残をきたさないよう脾摘にあ たっては脾静脈を下腸間膜静脈の流入部直前で結禁す ることが有効であるとする報告がみられる7.

脾摘後門脈血栓による主な臨床症状は腹痛, 腹満感, 便秘，下痢，嘔吐，下血，発熱などが知られている。 軽度なものでは血栓の自然消失や側副血行路の発達に より予後は良好であるが，血栓が広範囲に進展した場 合には腸管壊死，消化管出血，肝不全など致死的な合 併症ともなりうる

門脈血栓の治療薬としてウロキナーゼや組織プラス ミノーゲンアクチベータ（t-PA）を用いた血栓溶解療 法, ワーファリン，ヘパリンや AT-III製剤などを用い た抗凝固療法さらには血栓摘除術が知られている。し かしこれらの治療法は術後の使用には出血の危険性が 高くなるため適応は限られる。へパリンナトリウムは トロンビンの生成を直接阻害し血栓形成抑制に効果的 ではあるが，同時に止血栓形成をも直接阻害するのて 出血をきたしやすい，過剩に生成されたトロンビンは 凝固 V因子やVII因子を活性化し，その結果，活性型X 因子（Xa）を生成する。このXaがさらに大量なトロ ンビンを生成することになる。

これに対し今回自験例に有効性を認めたダナパロイ ドナトリウムはグリコサミノグリカンから成る低分子 ヘパリノイドである. 主としてアンチトロンビン III （AT-III）を介してXa 活性を抑制することによって トロンビン生成を抑制する。補助的に AT-IIIおよびへ パリンコファクターII（HC-II）を介してトロンビン 活性・トロンピンの生成および活性を抑制し，最終的 にはフィブリン形成を抑制する゙'。抗Xa/抗トロンビ
ン活性比はヘパリンナトリウムの1に対し，低分子へ パリンでは $2 \sim 4$ ，そしてダナパロイドナトリウムは 22.6である.このため出血を惹起せずに凝固活性化ポ テンシャルを効率よく隇少させることが出来る ${ }^{12)}$. ま た，血小板機能に対する作用が弱く，線溶活性に明ら かな影響を及ほさない。

出血に対する直接作用として in vitroで Meuleman らはラットの肢二頭股筋を切開した場合の筋出血量を 検討した，その結果，ダナパロイドナトリウムがへパ リンナトリウムの作用の約 $1 / 10$ であったと報告し た ${ }^{13)}$. 以上からダナパロイドナトリウムは出血の副作 用も少なく，脾摘後の門脈血栓のような術直後の使用 には最も適した薬剤といえる。また，1 日 2 回の静脈 内投与でよく，ヘパリンのように持続投与の必要がな いのも臨床上煩雑でなく患者の QOL も保たれる。な お，本剤は本邦で2000年 7 月より播種性血管内凝固症 候群 (DIC) のみを適応とし承認されたが，欧米では肺 血栓塞栓症, heparin-induced thrombocytopenia

(HIT) や門脈血栓などを含む深部静脈血栓症の予防 に対しても承認されている 患に対し適応が拡大されることが望まれる。

\section{文 献}

1）松田真佐男，小谷勝祥，伊藤正光他：脾摘後門脈 血栓症の 2 治験例. 日臨外医会誌 $47: 1102-$ 1110,1986

2）野村裕紀，桂巻 正，水口 徹他：巨大脾腫摘出 後の門脈内血栓症に対しダナパロイドナトリウム 投与が奏効した 1 例. 日臨外会誌 $64: 705-709$, 2003

3) Rossi P, Passariello R, Simonetti G, et al : Portal thrombosis: High incidence following splenectomy for portal hypertension. Gastrointest Radiol 1:225-227, 1976

4) Eguchi A, Hashizume M, Kitano S, et al : High rate of thrombosis after splenectomy in patients with esophageal varices and idiopathic portal hypertension. Arch Surg 126:752-755, 1991

5）山名秀明，掛川暉夫，小澡田盛一他：食道静脈瘤 における直達手術前後の門脈血行の変化一経皮経 肝門脈造影による検討一。 日消外会誌 15,1174 $-1180,1982$

6) Petit P, Bret PM, Atri M, et al : Splenic vein thrombosis after splenectomy : Frequency and 
role of imaging. Radiology $190: 65-68,1994$

7) Broe PJ, Conley CL, Cameron JL, et al : Thrombosis of the portal vein following splenectomy for myeloid metaplasia. Surg Gynecol Obstet $152: 488-492,1981$

8) Charleux $H$, Julien $M$, Vousquet $R$, et al : Les complications precoces de 777 splenectomies d' indications hematologiques. Chirurgie $100: 546$ $-550: 1974$

9) Balz J, Minton JP: Mesenteric thrombosis following splenectomy. Ann surg $181: 126-128$, 1975

10) Gordon GH, Schajjner D, Bennett JM, et al : Postsplenectomy thrombocytosis. Arch surg 113 : 713-715, 1978
11）高淵洋彰，过㹂，米田 充他：低分子ヘパリ ノイド (KB-101) の抗凝固作用特性と実験的 DIC に対する阻止効果の検討. 日血栓止血会誌 3 ： $169-177,1992$

12）岡嶋研二：話題の新薬 ダナパロイドナトリウ ム. Cardiac Prac 13:109-110, 2002

13) Meuleman DG, Hobbelen PM, van Dedem G, et al: A novel anti-thrombotic heparinoid (Org 10172) devoid of bleeding inducing capacity : a survey of its pharmacological properties in experimental animal models. Thromb Res 27 : $353-363,1982$

14) Ibbotson $T$, Perry $C M$ : Danaparoid : a review of its use in thromboembolic and coagulation disorders. Drugs $62: 2283-2314,2002$

\title{
A CASE OF PORTAL VEIN THROMBOSIS SUCCESSFULLY TREATED WITH DANAPAROID SODIUM AFTER SPLENECTOMY FOR HYPERSPLENISM
}

\author{
Kentaro YOKOTA, Hiroyuki ISHIZU, Yukifumi KONDO, \\ Kuniaki OKADA, Hiroyuki MASUKO and Ryoichi YOKOTA \\ Department of Surgery, JA Hokkaido Koseiren Sapporo Kosei Hospital
}

A 48-year-old female patient with liver cirrhosis (type C), hepatocellular carcinoma (HCC), splenomegaly and pancytopenia was referred to the department of surgery for undergoing splenectomy and resection of the tumor. Operation was successfully performed. Fever elevation persisted during the first four postoperative days, and abdominal computed tomography (CT) revealed portal vein thrombosis on the postoperative day 6 . Administration of danaparoid sodium was started on that day and portal vein thrombosis disappeared 12 days later on $\mathrm{CT}$.

Danaparoid sodium has a low risk of causing bleeding tendency, and because of this benefit, it could be safely used for portal vein thrombosis immediately after operation. Although danaparoid sodium can be indicated only for disseminated intravascular coagulation in Japan, it is widely indicated for deep venous thrombosis including pulmonary thrombosis in the Western countries. The effectiveness of the drug has also been demonstrated in this case. 